\title{
Lentibacillus lacisalsi sp. nov., a moderately halophilic bacterium isolated from a saline lake in China
}

Correspondence

Chang-Jin Kim changjin@kribb.re.kr

\author{
Jee-Min Lim, ${ }^{1}$ Che Ok Jeon, ${ }^{2}$ Sung-Min Song, ${ }^{1}$ Jae-Chan Lee, ${ }^{1}$ \\ Yoon Jung Ju, ${ }^{1}$ Li-Hua $\mathrm{Xu}^{3}{ }^{3}$ Cheng-Lin Jiang ${ }^{3}$ and Chang-Jin Kim ${ }^{1}$ \\ ${ }^{1}$ Korea Research Institute of Bioscience and Biotechnology, 52 Oeundong, Yusong, \\ Daejeon 305-333, Republic of Korea \\ ${ }^{2}$ Environmental Biotechnology National Core Research Center, Division of Environmental \\ Biotechnology, Gyeongsang National University, 660-701, Korea
}

${ }^{3}$ Yunnan Institute of Microbiology, Yunnan University, Kunming, Yunnan, 650091, P.R. China
Aerobic, spore-forming, moderately halophilic, Grampositive rods are taxonomically diverse and have been isolated from different marine environments and related habitats (Oren, 2002). They were originally assigned to the genus Bacillus (Ash et al., 1991; Stackebrandt \& Liesack, 1993; Nielsen et al., 1994; Ventosa et al., 1998), but molecular and chemical analyses have shown that they can be divided into several phylogenetically distinct lineages, such as the new genera Halobacillus (Spring et al., 1996), Gracilibacillus (Wainø et al., 1999), Virgibacillus (Heyndrickx et al., 1999), Filobacillus (Schlesner et al., 2001), Oceanobacillus (Lu et al., 2001), Tenuibacillus (Ren \& Zhou, 2005) and Pontibacillus (Lim et al., 2005).

Recently, novel species isolated from salty habitats, such as Lentibacillus juripiscarius and Lentibacillus salarius, have

Published online ahead of print on 15 April 2005 as DOI 10.1099/ ijs.0.63721-0.

The GenBank/EMBL/DDBJ accession number for the 16S rRNA gene sequence of strains $B H 260^{\top}$ is AY667497.

A transmission electron micrograph of a cell of strain $\mathrm{BH} 26 \mathrm{O}^{\top}$ is available as a supplementary figure in IJSEM Online. been added to the genus since the genus Lentibacillus was proposed for novel moderately halophilic Gram-positive rods (Yoon et al., 2002; Namwong et al., 2005; Jeon et al., 2005). In this study, polyphasic taxonomy demonstrated that another novel Gram-positive bacterium, strain $\mathrm{BH} 260^{\mathrm{T}}$, isolated from a salt lake in Xin-Jiang Province in China, represents a novel species of the genus Lentibacillus.

Strain $\mathrm{BH} 260^{\mathrm{T}}$ was isolated on marine agar 2216 (MA; Difco) with the addition of $20 \%(\mathrm{w} / \mathrm{v}) \mathrm{NaCl}$ [final concentration, $21.94 \%(\mathrm{w} / \mathrm{v}) \mathrm{NaCl}]$ at $28{ }^{\circ} \mathrm{C}$ for 3 days from soil sediment of a salt lake in China. Requirements for, and tolerance of, $\mathrm{NaCl}$ were determined in trypticase soy broth [TSB, containing $\left(1^{-1}\right) 17 \cdot 0 \mathrm{~g}$ casein, $3 \cdot 0 \mathrm{~g}$ soy-bean meal, $2 \cdot 5 \mathrm{~g}$ glucose, $5 \cdot 0 \mathrm{~g} \mathrm{NaCl}, 2 \cdot 5 \mathrm{~g}$ dipotassium phosphate] and supplemented with modified artificial sea water [containing $\left(\mathrm{l}^{-1}\right)$ 0-30\% (w/v) NaCl, 5.94 $\mathrm{g} \mathrm{MgSO}_{4} \cdot 7 \mathrm{H}_{2} \mathrm{O}$, $4.53 \mathrm{~g} \mathrm{MgCl}_{2} \cdot 6 \mathrm{H}_{2} \mathrm{O}, 0.64 \mathrm{~g} \mathrm{KCl}, 1.3 \mathrm{~g} \mathrm{CaCl}_{2}$ ]. Optimum growth was tested at different temperatures $\left(4-55^{\circ} \mathrm{C}\right)$ on MA containing $12 \%(\mathrm{w} / \mathrm{v}) \mathrm{NaCl}$ and at different $\mathrm{pH}$ values $(5 \cdot 0-11 \cdot 0)$ in TSB supplemented with artificial sea water containing $12 \%(\mathrm{w} / \mathrm{v}) \mathrm{NaCl}$. Anaerobic growth was determined by using incubation in an anaerobic chamber at $30^{\circ} \mathrm{C}$ 
for 5 days on MA containing $12 \%(\mathrm{w} / \mathrm{v}) \mathrm{NaCl}$. Cell morphology and flagellum type were studied using light microscopy (LABOPHOT apparatus; Nikon) and transmission electron microscopy (JEM-1010 apparatus; JEOL) as described by Lee et al. (2005). Motility was observed at 24 and $36 \mathrm{~h}$ in wet mounts by using a light microscope (E600; Nikon). Endospores were stained using Schaeffer-Fulton stain (Smibert \& Krieg, 1981).

Gram staining was determined using the bioMérieux Gram stain kit according to the manufacturer's instructions. Catalase activity was determined by assessing the production of oxygen bubbles in $3 \%(\mathrm{v} / \mathrm{v})$ aqueous hydrogen peroxide solution. Oxidase activity was tested for by assessing the oxidation of $1 \%(\mathrm{w} / \mathrm{v})$ tetramethyl- $p$ phenylenediamine (Merck). Hydrolysis of aesculin, casein, starch, Tween 80 , urea, hypoxanthine, tyrosine and xanthine was determined on MA, according to methods described previously (Lanyi, 1987; Smibert \& Krieg, 1994). Nitrate reduction was determined according to the method of Lanyi (1987). Acid production from carbohydrates was tested for as described by Leifson (1963); all suspension media were supplemented with artificial sea water containing $12 \%(\mathrm{w} / \mathrm{v}) \mathrm{NaCl}$. GC analysis of fatty acid methyl esters was performed using cells grown at $30^{\circ} \mathrm{C}$ for 3 days on MA with the addition of $10 \%(\mathrm{w} / \mathrm{v}) \mathrm{NaCl}$ according to the instructions of the Microbial Identification System (MIDI; Microbial ID). Analyses of peptidoglycan, polar lipids and isoprenoid quinones were carried out using the methods described by Komagata \& Suzuki (1987). The DNA G+C content of strain $\mathrm{BH} 260^{\mathrm{T}}$ was determined by reverse-phase HPLC (HP 1090 apparatus; Hewlett Packard) using the method of Tamaoka \& Komagata (1984).

Sequencing and assembly of the $16 \mathrm{~S}$ rRNA gene was carried out as described previously (Bakermans \& Madsen, 2002). The resultant 16S rRNA gene sequence was compared with available 16S rRNA gene sequences from GenBank by using the BLAST program (http://www.ncbi.nlm.nih.gov/ $\mathrm{BLAST} /$ ) and was aligned with closely related 16S rRNA gene sequences with CLUSTAL W software (Thompson et al., 1994). Sequence similarity values were computed using Similarity Matrix version 1.1 (Ribosomal Database Project II, http://35.8.164.52/html/; Cole et al., 2003). Phylogenetic trees were constructed using three different methods: neighbour-joining, maximum-likelihood and maximumparsimony algorithms available in PHYLIP software, version 3.6 (Felsenstein, 2002). Evolutionary distance matrices were calculated according to the algorithm of the Kimura twoparameter model (Kimura, 80) for the neighbour-joining method. To evaluate the stability of the phylogenetic tree, a bootstrap analysis (1000 replications) was performed with the SEQBOOT, DNADIST, NEIGHBOR and CONSENSE programs in the PHYLIP package.

Strain $\mathrm{BH} 260^{\mathrm{T}}$ on MA medium supplemented with $12 \%$ $(\mathrm{w} / \mathrm{v}) \mathrm{NaCl}$ formed cream-coloured, low-convex and circular/slightly irregular colonies and the colony morphologies were consistent at various salinities of $\mathrm{NaCl}$. Strain
$\mathrm{BH} 260^{\mathrm{T}}$ showed halophilic properties, growing in TSB containing 5-25\% (w/v) NaCl; optimum growth occurred in TSB with $12-15 \%(\mathrm{w} / \mathrm{v}) \mathrm{NaCl}$. Growth was not observed in the absence of $\mathrm{NaCl}$. Growth was observed at temperatures between 15 and $40{ }^{\circ} \mathrm{C}$, with optimum growth at $30-32^{\circ} \mathrm{C}$. Strain $\mathrm{BH} 260^{\mathrm{T}}$ grew at $\mathrm{pH}$ values in the range $7 \cdot 0-9 \cdot 5$ in $12 \%(\mathrm{w} / \mathrm{v}) \mathrm{NaCl}$-containing TSB; optimal growth was observed at $\mathrm{pH} 8 \cdot 0$. Cells of strain $\mathrm{BH} 260^{\mathrm{T}}$ from early and late growth phases showed obvious Grampositive reactions. The cells of the isolate were strictly aerobic, short rods, $0 \cdot 4-0 \cdot 6 \mu \mathrm{m}$ wide and $1 \cdot 2-3 \cdot 0 \mu \mathrm{m}$ long (see the transmission electron micrograph available as a supplementary figure in IJSEM Online). Cells of the isolate produced single spherical terminal endospores within swollen sporangia. Cell motility was facilitated by means of flagella on the sides of the cells. Anaerobic growth was not observed under anaerobic conditions after 5 days at $30^{\circ} \mathrm{C}$ on MA with $12 \%(\mathrm{w} / \mathrm{v}) \mathrm{NaCl}$.

The major respiratory lipoquinone of strain $\mathrm{BH} 260^{\mathrm{T}}$ was MK-7. The fatty acid profile of the strain was characterized by the presence of branched and saturated fatty acids such as anteiso- $\mathrm{C}_{15: 0}(50 \cdot 78 \%)$, anteiso- $\mathrm{C}_{17: 0}(18 \cdot 20 \%)$ and iso- $\mathrm{C}_{16: 0}(11.95 \%)$ as the major fatty acids, in common with the type strains of the genus Lentibacillus; their fatty acid compositions were somewhat different (Table 1). Cell-wall peptidoglycan analysis indicated $\mathrm{A} 1 \gamma$ type, mesodiaminopimelic acid as the diagnostic diamino acid. This peptidoglycan type is characteristic of Lentibacillus species (Yoon et al., 2002). The major polar lipids of the test

Table 1. Cellular fatty acid compositions of strain $\mathrm{BH} 260^{\top}$ and related taxa

Strains: 1, strain $\mathrm{BH} 260^{\mathrm{T}} ; 2$, L. salarius $\mathrm{KCTC} 3911^{\mathrm{T}}$; 3, L. salicampi KCCM $41560^{\mathrm{T}} ; 4$, L. juripiscarius JCM $12147^{\mathrm{T}} ; \quad$, Virgibacillus marismortui DSM $12325^{\mathrm{T}} ; 6, \quad$. carmonensis LMG $20964^{\mathrm{T}}$; 7, V. necropolis DSM $14866^{\mathrm{T}}$. Data are from Jeon et al. (2005), Yoon et al. (2002), Namwong et al. (2005), Arahal et al. (1999, 2000), Heyrman et al. (2003) and this study. Data are expressed as percentages of total fatty acids; fatty acids representing less than $0 \cdot 5 \%$ are not included. ND, Not detected.

\begin{tabular}{|c|c|c|c|c|c|c|c|}
\hline Fatty acid & 1 & 2 & 3 & 4 & 5 & 6 & 7 \\
\hline \multicolumn{8}{|l|}{ Straight-chain } \\
\hline $\mathrm{C}_{16: 0}$ & $1 \cdot 34$ & 0.99 & $1 \cdot 4$ & $\mathrm{ND}$ & $1 \cdot 1$ & $1 \cdot 13 \pm 0 \cdot 16$ & $1 \cdot 30$ \\
\hline \multicolumn{8}{|l|}{ Branched } \\
\hline iso- $\mathrm{C}_{14: 0}$ & $5 \cdot 70$ & $13 \cdot 91$ & $12 \cdot 0$ & $5-13$ & $3 \cdot 5$ & $3 \cdot 50 \pm 0 \cdot 36$ & $2 \cdot 95$ \\
\hline iso- $\mathrm{C}_{15: 0}$ & $8 \cdot 03$ & $16 \cdot 52$ & $3 \cdot 4$ & $3-18$ & $34 \cdot 4$ & $4 \cdot 56 \pm 0 \cdot 74$ & $4 \cdot 18$ \\
\hline anteiso- $\mathrm{C}_{15: 0}$ & $50 \cdot 78$ & $25 \cdot 34$ & $38 \cdot 6$ & $38-54$ & $31 \cdot 4$ & $65 \cdot 54 \pm 1 \cdot 40$ & $71 \cdot 50$ \\
\hline iso- $\mathrm{C}_{16: 0}$ & $11 \cdot 95$ & $26 \cdot 47$ & $30 \cdot 1$ & $13-30$ & $7 \cdot 6$ & $3 \cdot 65 \pm 0 \cdot 36$ & $3 \cdot 63$ \\
\hline iso- $\mathrm{C}_{17: 0}$ & $1 \cdot 91$ & $4 \cdot 38$ & $0 \cdot 7$ & ND & $7 \cdot 6$ & $\mathrm{ND}$ & $\mathrm{ND}$ \\
\hline anteiso- $\mathrm{C}_{17: 0}$ & $18 \cdot 20$ & $11 \cdot 51$ & $13 \cdot 4$ & $13-18$ & $10 \cdot 9$ & $9 \cdot 43 \pm 0 \cdot 28$ & $9 \cdot 33$ \\
\hline \multicolumn{8}{|l|}{ Unsaturated } \\
\hline $\begin{array}{c}\mathrm{C}_{16: 1} \omega 7 c \\
\text { alcohol }\end{array}$ & $1 \cdot 47$ & ND & $0 \cdot 5$ & ND & $1 \cdot 0$ & $5 \cdot 01 \pm 0 \cdot 59$ & $2 \cdot 45$ \\
\hline
\end{tabular}


strain were diphosphatidylglycerol and phosphatidylglycerol. The genomic DNA $\mathrm{G}+\mathrm{C}$ content of strain $\mathrm{BH} 139^{\mathrm{T}}$ was $44 \mathrm{~mol} \%$, a value that falls within the defined range for the genus Lentibacillus (Jeon et al., 2005). The major fatty acid profile, the major lipoquinone, the cell-wall type and the DNA G $+\mathrm{C}$ content of strain $\mathrm{BH} 260^{\mathrm{T}}$ were typical of the genus Lentibacillus (Table 2).

Phylogenetic analysis based on 16S rRNA gene sequences showed that strain $\mathrm{BH} 260^{\mathrm{T}}$ is located in a clade that includes the type strains of $L$. salarius, $L$. juripiscarius and Lentibacillus salicampi in the neighbour-joining analysis (Fig. 1). The topologies of phylogenetic trees obtained using the maximum-likelihood and maximum-parsimony algorithms were similar to that of the tree constructed using neighbour-joining analysis (data not shown). The levels of $16 \mathrm{~S}$ rRNA gene sequence similarity for strain $\mathrm{BH} 260^{\mathrm{T}}$ with respect to Lentibacillus salsus KCTC $3911^{\mathrm{T}}$, L. juripiscarius
JCM $12147^{\mathrm{T}}$ and L. salicampi KCCM $41560^{\mathrm{T}}$ were $96 \cdot 0,95 \cdot 5$ and $95.3 \%$, respectively - values that are generally sufficient to define a novel species (Rosselló-Mora \& Amann, 2001; Stackebrandt et al., 2002).

On the basis of the polyphasic taxonomic evidence, we classify strain $\mathrm{BH} 260^{\mathrm{T}}$ as a novel Lentibacillus species, for which the name Lentibacillus lacisalsi sp. nov. is proposed.

\section{Description of Lentibacillus lacisalsi sp. nov.}

Lentibacillus lacisalsi (la.ci.sal'si. L. masc. n. lacus lake; L. adj. salsus - $a$-um salted, salt; N.L. gen. n. lacisalsi of a salt lake).

Cells are approximately $0 \cdot 4-0 \cdot 6 \mu \mathrm{m}$ wide and $1 \cdot 2-3 \cdot 0 \mu \mathrm{m}$ long, strictly aerobic, motile rods with peritrichous flagella. Colonies are cream-coloured, low-convex and circular/ slightly irregular on MA supplemented with $10 \%(\mathrm{w} / \mathrm{v})$ $\mathrm{NaCl}$. Growth occurs at $15-40{ }^{\circ} \mathrm{C}$ (optimum, $30-32^{\circ} \mathrm{C}$ ),

Table 2. Characteristics of strain $B H 260^{\top}$ and some other related species

Strains: 1, strain $\mathrm{BH} 260^{\mathrm{T}}$; 2, L. salarius $\mathrm{KCTC} 3911^{\mathrm{T}}$; 3, L. salicampi $\mathrm{KCCM} 41560^{\mathrm{T}}$; 4. L. juripiscarius JCM $12147^{\mathrm{T}}$ 5, V. marismortui DSM $12325^{\mathrm{T}} ; 6$, V. carmonensis LMG $20964^{\mathrm{T}}$; 7, V. necropolis DSM $14866^{\mathrm{T}}$. Data are from Jeon et al. (2005), Yoon et al. (2002), Namwong et al. (2005), Arahal et al. (1999, 2000), Heyrman et al. (2003) and this study. Symbols: +, positive; -, negative; W, weak; NA, not available.

\begin{tabular}{|c|c|c|c|c|c|c|c|}
\hline Characteristic & 1 & 2 & 3 & 4 & 5 & 6 & 7 \\
\hline \multicolumn{8}{|l|}{ Sporangia } \\
\hline Spore shape ${ }^{\star}$ & s & s/O & s/o & $\mathrm{O}$ & $\mathrm{E}$ & $\mathrm{E}(\mathrm{s})$ & $\mathrm{E}$ \\
\hline Spore position $\dagger$ & $\mathrm{T}$ & $\mathrm{T}$ & $\mathrm{T}$ & $\mathrm{T}$ & $\mathrm{T} / \mathrm{ST}$ & ST & $\mathrm{C} / \mathrm{sT}$ \\
\hline Motility & + & + & + & - & + & + & + \\
\hline Temperature range $\left({ }^{\circ} \mathrm{C}\right)$ & $15-40$ & $15-50$ & $15-40$ & $10-45$ & $15-50$ & $10-40$ & $10-40$ \\
\hline $\mathrm{NaCl}$ range $(\%, \mathrm{w} / \mathrm{v})$ & $5-25$ & $1-20$ & $2-23$ & $3-30$ & $5-25$ & NA & NA \\
\hline Oxidase & + & - & + & + & + & NA & NA \\
\hline Nitrate reduction & + & + & NA & + & - & + & + \\
\hline \multicolumn{8}{|l|}{ Hydrolysis } \\
\hline Aesculin & - & + & - & NA & + & $\mathrm{W}$ & - \\
\hline Casein & - & - & + & + & + & + & + \\
\hline Tween 80 & - & - & + & + & - & NA & NA \\
\hline Urea & - & - & - & - & + & NA & NA \\
\hline \multicolumn{8}{|l|}{ Acid production from: } \\
\hline D-Glucose & - & + & - & + & + & - & $\mathrm{W}$ \\
\hline D-Fructose & + & + & - & + & + & - & $\mathrm{W}$ \\
\hline D-Mannitol & - & $\mathrm{W}$ & - & - & - & - & - \\
\hline D-Ribose & + & + & - & + & NA & $\mathrm{NA}$ & + \\
\hline D-Xylose & $\mathrm{W}$ & + & - & + & - & NA & + \\
\hline Maltose & - & + & - & - & + & NA & NA \\
\hline D-Trehalose & - & $\mathrm{W}$ & - & - & - & - & $\mathrm{w}$ \\
\hline D-Arabinose & $\mathrm{W}$ & $\mathrm{w}$ & - & - & - & - & - \\
\hline D-Mannose & - & + & - & - & - & - & $\mathrm{W}$ \\
\hline Cell-wall type $\ddagger$ & $m$-DAP & NA & $m$-DAP & $m$-DAP & $m$-DAP & $\mathrm{NA}$ & NA \\
\hline DNA G $+\mathrm{C}$ content $(\mathrm{mol} \%)$ & 44 & 43 & 44 & 43 & $40 \cdot 7$ & $38 \cdot 9$ & $37 \cdot 3$ \\
\hline
\end{tabular}

${ }^{\star} \mathrm{E}$, Ellipsoidal; S, spherical; O, oval.

$\dagger \mathrm{C}$, Central; T, terminal; ST, subterminal.

$\ddagger m$-DAP, meso-Diaminopimelic acid. 


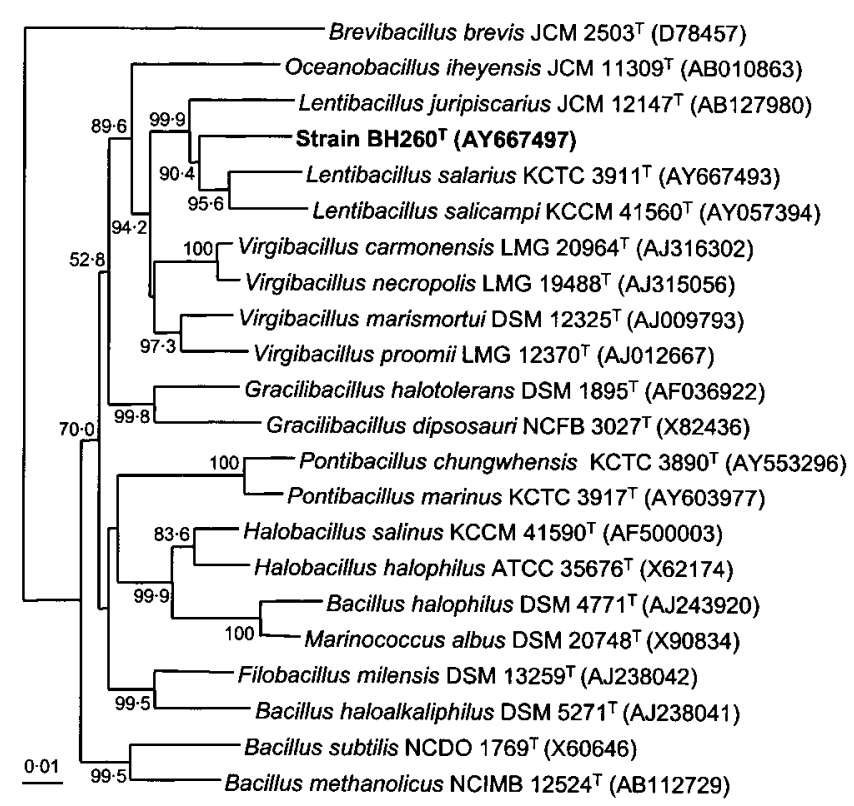

Fig. 1. Neighbour-joining tree showing phylogenetic relationships based on $16 \mathrm{~S}$ rRNA gene sequences of strain $\mathrm{BH} 260^{\top}$ and other related taxa. Bootstrap values are presented as percentages of 1000 replicates; only values above $50 \%$ are shown. Brevibacillus brevis JCM $2503^{\top}$ was used as an outgroup. Bar, $0 \cdot 01$ changes per nucleotide position.

pH 7·0-9.5 (optimum, pH 8.0) and 5-25\% (w/v) $\mathrm{NaCl}$ (optimum, 12-15\%). Nitrate is reduced to nitrite. Hydrolysis of urea, L-tyrosine, hypoxanthine, casein, starch, Tween 80 , aesculin and xanthine is not observed. Acids produced from D-fructose, D-ribose, D-xylose and L-arabinose but not from glycerol, D-glucose, maltose, D-trehalose, $\alpha$-D-lactose, D-mannitol, D-mannose, rhamnose, adonitol, raffinose, arbutin, D-salicin or D-melibiose. The major isoprenoid quinone is MK-7. Cell wall contains meso-diaminopimelic acid (A1 $\gamma$ type). The predominant polar lipids are phosphatidylglycerol and diphosphatidylglycerol. The major fatty acids are anteiso- $\mathrm{C}_{15: 0}$, anteiso- $\mathrm{C}_{17: 0}$ and iso- $\mathrm{C}_{16: 0}$. The DNA G $+\mathrm{C}$ content is $44 \mathrm{~mol} \%$ (by HPLC).

The type strain, BH260 ${ }^{\mathrm{T}}\left(=\mathrm{KCTC} 3915^{\mathrm{T}}=\mathrm{DSM} 16462^{\mathrm{T}}\right)$, was isolated from a salt lake in China.

\section{Acknowledgements}

This work was supported by the 21C Frontier Microbial Genomics and Application Center Program, Ministry of Science and Technology (grant MG05-0101-1-0) and the International Cooperation R\&D Program, Ministry of Science and Technology (grant M6-0203-000002), Republic of Korea.

\section{References}

Arahal, D. R., Marquez, M. C., Volcani, B. E., Schleifer, K. H. \& Ventosa, A. (1999). Bacillus marismortui sp. nov., a new moderately halophilic species from the Dead Sea. Int J Syst Bacteriol 49, 521-530.
Arahal, D. R., Marquez, M. C., Volcani, B. E., Schleifer, K. H. \& Ventosa, A. (2000). Reclassification of Bacillus marismortui as Salibacillus marismortui comb. nov. Int J Syst Evol Microbiol 50, 1501-1503.

Ash, C., Farrow, J. A. E., Wallbanks, S. \& Collins, M. D. (1991). Phylogenetic heterogeneity of the genus Bacillus as revealed by comparative analysis of small-subunit ribosomal-RNA sequences. Lett Appl Microbiol 13, 202-206.

Bakermans, C. \& Madsen, E. L. (2002). Diversity of $16 \mathrm{~S}$ rDNA and naphthalene dioxygenase genes from coal-tar-waste-contaminated aquifer waters. Microb Ecol 44, 95-106.

Cole, J. R., Chai, B., Marsh, T. L. \& 8 other authors (2003). The ribosomal database project (RDP-II): previewing a new autoaligner that allows regular updates and the new prokaryotic taxonomy. Nucleic Acids Res 31, 442-443.

Felsenstein, J. (2002). PHYLIP - Phylogeny Inference Package, version 3.6a. Seattle, WA: University of Washington.

Heyndrickx, M., Lebbe, L., Kersters, K., De Vos, P., Forsyth, G. \& Logan, N. A. (1999). Virgibacillus: a new genus to accommodate Bacillus pantothenticus (Proom and Knight 1950). Emended description of Virgibacillus pantothenticus. Int J Syst Bacteriol 48, 99-106.

Heyrman, J., Logan, N. A., Busse, H. J., Balcaen, A., Lebbe, L., Rodriguez-Diaz, M., Swings, J. \& De Vos, P. (2003). Virgibacillus carmonensis sp. nov., Virgibacillus necropolis sp. nov. and Virgibacillus picturae sp. nov., three novel species isolated from deteriorated mural paintings, transfer of the species of the genus Salibacillus to Virgibacillus, as Virgibacillus marismortui comb. nov. and Virgibacillus salexigens comb. nov., and emended description of the genus Virgibacillus. Int J Syst Evol Microbiol 53, 501-511.

Jeon, C. O., Lim, J.-M., Lee, J. C., Lee, G. S., Lee, J.-M., Xu, L.-H., Jiang, C.-L. \& Kim, C.-J. (2005). Lentibacillus salarius sp. nov., isolated from saline sediment in China, and emended description of the genus Lentibacillus. Int J Syst Evol Microbiol 55, 1339-1343.

Kimura, M. (1980). A simple method for estimating evolutionary rates of base substitutions through comparative studies of nucleotide sequences. J Mol Evol 16, 111-120.

Komagata, K. \& Suzuki, K. (1987). Lipid and cell-wall analysis in bacterial systematics. Methods Microbiol 19, 161-208.

Lanyi, B. (1987). Classical and rapid identification methods for medically important bacteria. Methods Microbiol 19, 1-67.

Lee, E. M., Jeon, C. O., Choi, I., Chang, K. S. \& Kim, C. J. (2005). Silanimonas lenta gen. nov., sp. nov., a slightly thermophilic and alkaliphilic gammaproteobacterium isolated from a hot spring. Int J Syst Evol Microbiol 55, 385-389.

Leifson, E. (1963). Determination of carbohydrate metabolism of marine bacteria. J Bacteriol 85, 1183-1184.

Lim, J.-M., Jeon, C. O., Song, S. M. \& Kim, C.-J. (2005). Pontibacillus chungwhensis gen. nov., sp. nov., a moderately halophilic Grampositive bacterium from a solar saltern in Korea. Int J Syst Evol Microbiol 55, 165-170.

Lu, J., Nogi, Y. \& Takami, H. (2001). Oceanobacillus iheyensis gen. nov., sp. nov., a deep-sea extremely halotolerant and alkaliphilic species isolated from a depth of $1050 \mathrm{~m}$ on the Iheya Ridge. FEMS Microbiol Lett 205, 291-297.

Namwong, S., Tanasupawat, S., Smitinont, T., Visessanguan, W., Kudo, T. \& Itoh, T. (2005). Characterization of Lentibacillus salicampi strains and Lentibacillus juripiscarius sp. nov. isolated from fish sauce in Thailand. Int J Syst Evol Microbiol 55, 315-320.

Nielsen, P., Rainey, F. A., Outtrup, H., Priest, F. G. \& Fritze, D. (1994). Comparative $16 \mathrm{~S}$ rDNA sequence analysis of some 
alkaliphilic bacilli and the establishment of a sixth rRNA group within the genus Bacillus. FEMS Microbiol Lett 117, 61-66.

Oren, A. (2002). Diversity of halophilic microorganisms: environments, phylogeny, physiology, and applications. J Ind Microbiol Biotechnol 28, 56-63.

Ren, P. G. \& Zhou, P. J. (2005). Tenuibacillus multivorans gen. nov., sp. nov., a moderately halophilic bacterium isolated from saline soil in Xin-Jiang, China. Int J Syst Evol Microbiol 55, 95-99.

Rosselló-Mora, R. \& Amann, R. (2001). The species concept for prokaryotes. FEMS Microbiol Rev 25, 39-67.

Schlesner, H., Lawson, P. A., Collins, M. D., Weiss, N., Wehmeyer, U., Völker, H. \& Thomm, M. (2001). Filobacillus milensis gen. nov., sp. nov., a new halophilic spore-forming bacterium with Orn-D-Glutype peptidoglycan. Int J Syst Evol Microbiol 51, 425-431.

Smibert, R. M. \& Krieg, N. R. (1981). General characterization. In Manual of Methods for General Microbiology, pp. 409-443. Edited by P. Gerhardt, R. G. E. Murray, R. N. Costilow, E. W. Nester, W. A. Wood, N. R. Krieg \& G. B. Phillips. Washington, DC: American Society for Microbiology.

Smibert, R. M. \& Krieg, N. R. (1994). Phenotypic characterization. In Methods for General and Molecular Bacteriology, pp. 607-654. Edited by P. Gerhardt. Washington, DC: American Society for Microbiology.

Spring, S., Ludwig, W., Marquez, M. C., Ventosa, A. \& Schleifer, K.-H. (1996). Halobacillus gen. nov., with description of Halobacillus litoralis sp. nov. and Halobacillus trueperi sp. nov., and transfer of Sporosarcina halophila to Halobacillus halophila comb. nov. Int J Syst Bacteriol 46, 492-496.
Stackebrandt, E. \& Liesack, W. (1993). Nucleic acids and classification. In Handbook of New Bacterial Systematics, pp. 152-189. Edited by M. Goodfellow \& A. G. O’Donnell. London: Academic Press.

Stackebrandt, E., Frederiksen, W., Garrity, G. M. \& 10 other authors (2002). Report of the ad hoc committee for the re-evaluation of the species definition in bacteriology. Int J Syst Evol Microbiol 52, 1043-1047.

Tamaoka, J. \& Komagata, K. (1984). Determination of DNA base composition by reverse-phase high-performance liquid chromatography. FEMS Microbiol Lett 25, 125-128.

Thompson, J. D., Higgins, D. G. \& Gibson, T. J. (1994). CLUSTAL W: improving the sensitivity of progressive multiple sequence alignment through sequence weighting, position-specific gap penalties and weight matrix choice. Nucleic Acids Res 22, 4673-4680.

Ventosa, A., Nieto, J. J. \& Oren, A. (1998). Biology of moderately halophilic aerobic bacteria. Microbiol Mol Biol Rev 62, 504-544.

Wainø, M., Tindall, B. J., Schumann, P. \& Ingvorsen, K. (1999). Gracilibacillus gen. nov., with description of Gracilibacillus halotolerans gen. nov., sp. nov.; transfer of Bacillus dipsosauri to Gracilibacillus dipsosauri comb. nov., and Bacillus salexigens to the genus Salibacillus gen. nov., as Salibacillus salexigens comb. nov. Int J Syst Bacteriol 49, 821-831.

Yoon, J. H., Kang, K. H. \& Park, Y. H. (2002). Lentibacillus salicampi gen. nov., sp. nov., a moderately halophilic bacterium isolated from a salt field in Korea. Int J Syst Evol Microbiol 52, 2043-2048. 